\title{
NOTES ON THE GROWTH AND BIOLOGY OF THE PRAWN PANDALUS BONNIERI CAULLERY
}

\author{
By R. B. Pike \\ The Marine Station, Millport
}

(Text-figs. I and 2)

Pandalus bonnieri Caullery has for a long time been known to occur in considerable numbers in the deeper waters of the Clyde Sea Area. Its life history and growth have been investigated, with special reference to sexual development, since the genus Pandalus contains not only species that are dioecious, but also those that are protandrous.

The author expresses indebtedness to the skipper and crew of M.V. Calanus for their unfailing help in collecting the material, and to Miss E. R. Wallace for assistance in measuring specimens. Thanks are also due to Dr A. Ritchie at the Fisheries Laboratory, Aberdeen, for supplying records of the occurrence of $P$. bonnieri on the west coast of Scotland and in the North Sea, and to colleagues at the Marine Station for assistance in preparing this paper.

\section{Collection of Material and Data}

All adult prawns were caught in the Firth of Clyde on trawling grounds off the Island of Bute (National Grid Reference 26/II59-II62) at a depth of 70-90 m. The gear used was an $8 \mathrm{ft}$. Agassiz trawl having a net mesh of $\frac{1}{2}$ in. bar, which was found to retain prawns above $7 \mathrm{~mm}$. carapace length $(3.7 \mathrm{~cm}$. total length). The duration of a haul was 15 min., and such hauls were repeated until a sufficient number of specimens had been obtained for the day's sample.

For catching prawns smaller than $7 \mathrm{~mm}$. carapace length, a $2 \mathrm{~m}$. stramin net was fixed to a small beam trawl, so modified that the net worked about 6 in. above the muddy bottom. Early post-larval stages were seldom obtained in any numbers.

All specimens above $5 \mathrm{~mm}$. carapace length were measured with fine calipers in the fresh condition and then fixed in 10\% formalin for subsequent preservation in $70 \%$ alcohol.

The standard measurement made was the 'length of the carapace', being the distance from the posterior margin of the eye socket to the dorsal posterior 
margin of the carapace. Measurement was made to the nearest I $\mathrm{mm}$. below, and the data were recorded in $\mathrm{I} \mathrm{mm}$. groups.

An approximation to the total length, including the rostrum, can be obtained by multiplying the carapace length in the male by 5.2 , and in the female and juvenile by 5.4 . In both males and females of carapace length exceeding $17 \mathrm{~mm}$., however, the total length calculated in this manner works out on the high side.

\section{Geographical Distribution}

$P$. bonnieri Caullery is essentially a deep-water prawn and, like $P$. borealis Krøyer, is usually found at a depth of about $100 \mathrm{~m}$. Its distribution extends from Iceland (Stephensen, I939, p. 22) to the Bay of Biscay (Caullery, I896). It does not appear to be very plentiful round Iceland or to enter Greenland waters. From Norway it is recorded by Wollebaek (1908) from several localities in both the south and west. Dr Ritchie has kindly supplied me with sixty records of its occurrence in the North Sea and from the west coast of Scotland. These records show that it is taken frequently in the North Sea from the Shetland Isles to Peterhead, and on one occasion was taken as far south as $56^{\circ} 03^{\prime} \mathrm{N}$., $\mathrm{I}^{\circ} 45^{\prime} \mathrm{W}$. The majority of specimens were obtained beyond the $100 \mathrm{~m}$. line along the western edge of the deep central basin of the North Sea, but they were not abundant at any locality. On the west coast of Scotland it is also taken beyond the $100 \mathrm{~m}$. line and appears to be generally distributed, the greatest numbers being obtained off the Butt of Lewis and south of South Uist. In general, records are absent for the north of Scotland and west of the Outer Hebrides, but the prawn has been obtained on two occasions west of the Orkneys. Dr Ritchie suggests that their absence from these areas may be due to the texture of the sea-floor in those localities. Calman (I899) was the first to record it from the Firth of Clyde. He also records it from the west coast of Ireland and off Rockall. Kemp (I9IO) states that it is abundant in the Irish Sea and off the west coast of Ireland, but it has not so far been taken off the south of Ireland. It is not recorded in the Marine Fauna of the Isle of Man (Moore, I937), but Mr N. S. Jones of the Marine Biological Station, Port Erin, informs me that he has taken it frequently since I 946 on muddy bottom in 90-I30 m., 7-II miles north-west of Bradda Head. It does not appear in the Plymouth Marine Fauna (Mar. Biol. Assoc., I93I). Lebour (I940), however, records the larvae as occurring in plankton off Seven Stones Lightship, Scilly Isles ( $50^{\circ} 03 \frac{1}{2}^{\prime}$ N., $6^{\circ} 04 \frac{1}{2}^{\prime} \mathrm{W}$.).

\section{OCCURRENCE IN THE CLYde}

In the Clyde $P$. bonnieri is taken frequently in water as shallow as $40 \mathrm{~m}$., although it is most abundant at depths of 90-130 m., on grounds composed of soft grey mud, inhabited by an animal community.similar to that associated with $P$. borealis as described by Hjort \& Ruud (1938). 
The commonest bivalve molluscs are Abra alba (Wood) and various species of Nucula, of which N. nucleus (L.) and N. sulcata Bronn are the commonest. Thyasira flexuosa (Montagu) is, however, rare and Chlamys septemradiata (Müller) is not very abundant on this ground. Among the annelids, Pectinaria belgica (Pallas), Lipobranchius jeffreysii (McIntosh) and Glycera rouxi Audouin \& M.-Edwards are all very plentiful. Of the Crustacea, Spirontocaris spinus var. lilljeborgi (Danielssen), Crangon allmani Kinahan and Nephrops norvegicus $\mathrm{L}$. are the commonest species.

\section{MigRaTION}

Berkeley (I93I) drew attention to evidence that larvae of pandalids metamorphose in shallow water, and Poulsen (1946) also found young Pandalus borealis in shallow water round Denmark. In the Clyde the normal prawn grounds, and the shallow water areas in the neighbourhood, were trawled with a bottom stramin net (see collection of material and data) during June and July I95I for early metamorphosed prawns. These were not obtained in any numbers until 3I July at a depth of $130 \mathrm{~m}$. No information was therefore obtained on the movements of young $P$. bonnieri.

Adult prawns could not be found during August and September I95I in the Clyde. According to Hjort \& Ruud (1938) P. borealis rises off the bottom during dull weather and during the hours of darkness. A similar habit in $P$. bonnieri might account for the difference in numbers on successive days, but not for the scarcity of specimens during two months. It is possible that both the young and adults moved into the nearby inshore boulder-strewn grounds where trawling was impossible.

\section{BREEDING}

In the Clyde the ovaries of adult prawns begin to mature in July, when they show through the carapace as a greenish mass. In September the fully ripe ovaries darken to a deep sage green. Egg-laying begins at the end of October with the larger size-groups laying first (Fig. IA), and continues for about 6-8 weeks. By the end of December the whole adult female population is in berry (Fig. IB).

The eggs when first laid are a beautiful deep green colour and oval in shape (c. $2 \times \mathrm{I} .5 \mathrm{~mm}$.). The sage-green colour of the newly laid egg in $P$. bonnieri is in contrast with the blue-green egg of $P$. borealis, the light emerald green of $P$. montagui Leach and the fawn colour in P. propinquus G. O. Sars.

The green colour gradually disappears as the larvae develop, and just before hatching takes place the green is almost replaced by pale violet and yellow pigmentation with the prominent red chromatophores of the thoracic region clearly showing. The eye pigmentation develops gradually and is first seen after about 3 months' incubation. 


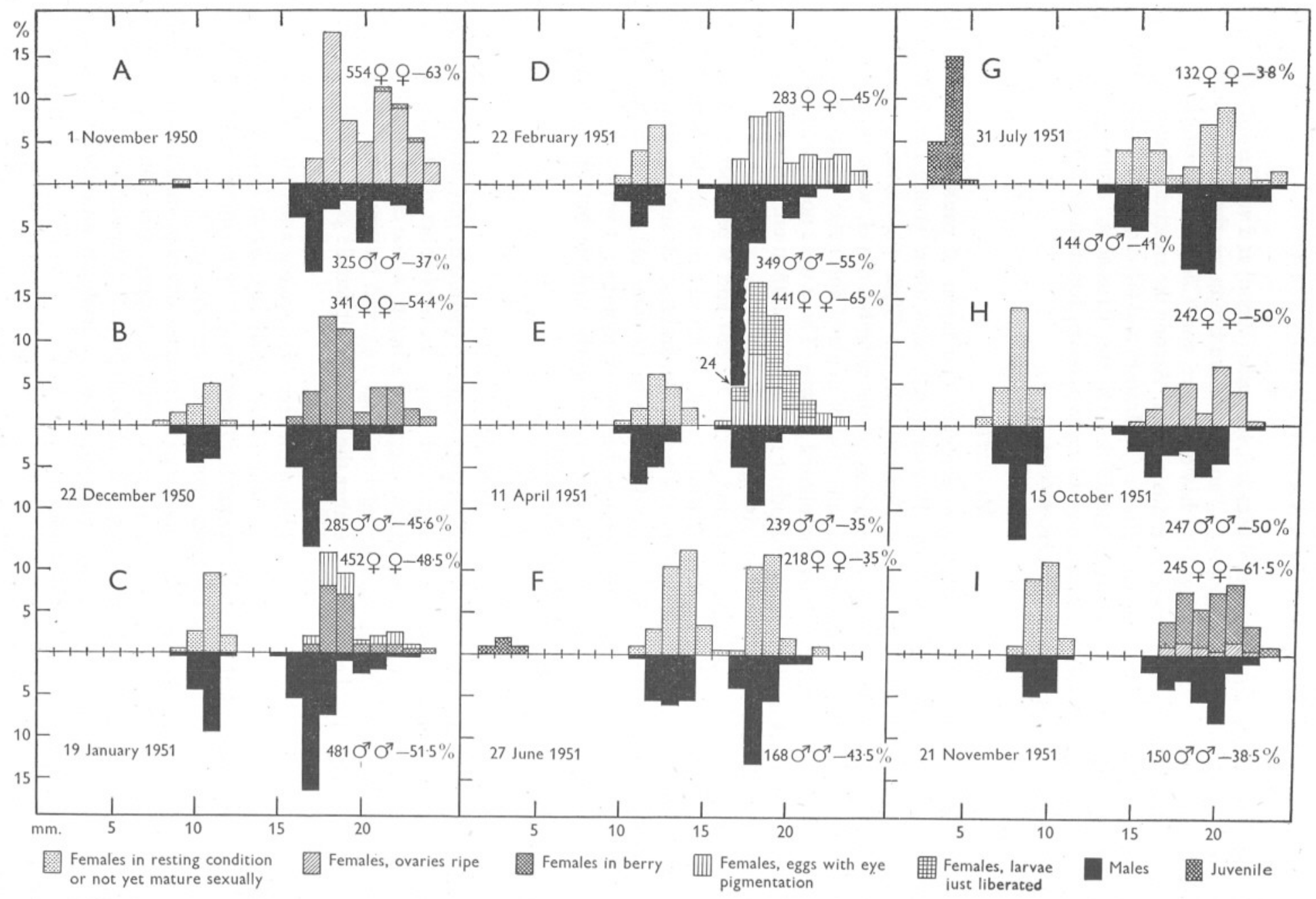

Fig. I. 
The number of eggs laid by $P$. bonnieri increases from approximately 1000 at $16 \mathrm{~mm}$. carapace length to 4000 at $24 \mathrm{~mm}$. carapace length. Within any given millimetre size-group the variation appears to be $c . \pm 10 \%$.

In I95I the first larvae were liberated in the third week in February, although the number of prawns that had completed incubation was too small to be recorded on the graph for 22 February (Fig. ID). The total hatching period extended over 2 months and all the larvae were liberated by the end of April (Table I).

It is probable that moulting and the loss of the ovigerous setae take place within Io days of the liberation of the larvae from the eggs, but the period is not known. Höglund (1943) has described and illustrated the ovigerous setae for $P$. borealis and shown the arrangement to be similar for $P$. bonnieri.

\section{Table I. Breeding Condition In Second- And Third-year PANDALUS BONNIERI}

$\begin{array}{ccccc}\begin{array}{c}\text { Date } \\ \text { (I950-I) }\end{array} & \begin{array}{c}\text { Ovary ripe } \\ (\%)\end{array} & \begin{array}{c}\text { Eggs } \\ (\%)\end{array} & \begin{array}{c}\text { Eggs with eye } \\ \text { pigmentation } \\ (\%)\end{array} & \begin{array}{c}\text { Larvae } \\ \text { liberated } \\ (\%)\end{array} \\ \text { I5 Oct. } & 100 & - & - & - \\ \text { 26 Nov. } & 22 & 78 & - & - \\ \text { 6 Dec. } & 3 & 97 & - & - \\ \text { I9 Jan. } & - & 60 & 40 & - \\ \text { 22 Feb. } & - & - & 98 & 2 \\ \text { I9 Mar. } & - & - & 90 & 10 \\ \text { II Apr. } & - & - & 54 & 46 \\ \text { 5 May } & - & - & - & 100\end{array}$

\section{SeXUAL Differentiation in PANDALUS BONNIERI.}

Over one whole year, the percentage of males in the catches has varied between 35 and $55 \%$, about a mean of $45 \%$, and that of the females between 38 and $65 \%$, about a mean of $55 \%$. The sex was determined by the examination of the pleopods under the binocular microscope. The sex characters of $P$. bonnieri agree very closely with those given by Wollebaek (1908) for P. borealis. Among the males no transitional form of pleopod corresponding to that illustrated by Jägersten (1936) for $P$. borealis was found.

Many male prawns were dissected, but not one was found to possess oviducts as well as vasa deferentia. Sections of the male gonad in prawns aged I8-30 months have been prepared, from which it could be seen that the gonad

\section{Legend to Fig. I.}

Fig. I. The percentage size distribution of Pandalus bonnieri in the Clyde Sea Area during 1950-5I. Females above and males below the zero line. To the left the date of collection. To the right the number of females and males measured in each sample in total and in percentage of the whole sample. The juvenile population in Fig. I is included in the total percentage although captured with a different gear (see p. 259). In the females the state of sexual maturity is also shown. 
was composed entirely of testicular tissue with no trace of ovarian tissue such as was found by Jägersten in $P$. borealis.

I therefore think $P$. bonnieri is completely dioecious. This finding is confirmed by Dr Ritchie in a personal communication.

\section{Rate OF GROWTH IN PANDALUS BONNIERI}

The data obtained on growth are shown in graphic form in Figs. I and 2 and summarized in Table II.

In preparing Fig. 2 the graph relates to modal lengths and not to arithmetic means as were used by Hjort \& Ruud (I938) for P. borealis, by Höglund (I943) for Leander squilla (L.) and by Forster (195I, $a, b)$ for both L. squilla and L. serratus Pennant.

\section{TABLE II. GROWTH OF PANDALUS BONNIERI}

\begin{tabular}{|c|c|c|c|c|c|c|}
\hline \multirow[b]{2}{*}{$\begin{array}{l}\text { Month } \\
\text { of year }\end{array}$} & \multicolumn{2}{|c|}{ O-Group } & \multicolumn{2}{|c|}{ I-Group } & \multicolumn{2}{|c|}{ II-Group } \\
\hline & $\begin{array}{l}\text { Age in } \\
\text { months }\end{array}$ & $\begin{array}{l}\text { Carapace } \\
\text { length } \\
(\mathrm{mm} .)\end{array}$ & $\begin{array}{l}\text { Age in } \\
\text { months }\end{array}$ & $\begin{array}{c}\text { Carapace } \\
\text { length } \\
(\mathrm{mm} .)\end{array}$ & $\begin{array}{l}\text { Age in } \\
\text { months }\end{array}$ & $\begin{array}{l}\text { Carapace } \\
\text { length } \\
(\mathrm{mm} .)\end{array}$ \\
\hline Apr. & $0-2$ & $0.9-I \cdot 2$ & $\mathrm{I} 2-\mathrm{I} 4$ & $\begin{array}{rr}0 & \mathrm{II}-\mathrm{I} 2 \\
+ & \mathrm{I} 2\end{array}$ & $24-26$ & $\begin{array}{lr}0 & 18 \\
0 & 18 \\
0 & 19\end{array}$ \\
\hline June & $2-4$ & $2 \cdot 5-3 \cdot 0$ & I4-I6 & $\begin{array}{l}\hat{0} \mathrm{I} 2-\mathrm{I} 4 \\
\text { ○ I3-I4 }\end{array}$ & $26-28$ & $\begin{array}{lr}0 & 18 \\
0 & 18-19\end{array}$ \\
\hline July & $3-5$ & $3-5$ & I5-I7 & $\begin{array}{rr}0 & 14-15 \\
0 & \text { I5 }\end{array}$ & $27-29$ & $\begin{array}{l}\text { o } 18-19 \\
\text { ᄋ } 19-20\end{array}$ \\
\hline Oct. & $6-8$ & 중우 7-9 & I8-20 & $\begin{array}{lr}0 & 16 \\
0 & 16 \\
9 & 17-18\end{array}$ & $30-32$ & $\begin{array}{ll}0 & 19 \\
0 & 20 \\
0 & \end{array}$ \\
\hline Nov. & $7-9$ & 궁 9-10 & I9-2I & $\begin{array}{ll}0 & \text { I7 } \\
\text { + } & \text { I8 }\end{array}$ & $3 I-33$ & $\begin{array}{lr}0 & 20 \\
& 20 \\
+ & 21-22\end{array}$ \\
\hline Dec. & 8-10 & 궁 IO-II & $20-22$ & $\begin{array}{lr}1 & \text { I7 } \\
0 & \text { I8- } 19\end{array}$ & $32-34$ & $\begin{array}{lr}0 & 20 \\
0 & 21-22\end{array}$ \\
\hline Jan. & 9-II & ㅇํㅇ IO-II & $2 I-23$ & $\begin{array}{lr}0 & \text { I7 } \\
0 & \text { I8 } \\
0 & -199\end{array}$ & $33-35$ & $\begin{array}{ll}0 & 20 \\
0 & 22 \\
+ & 22\end{array}$ \\
\hline Feb. & IO-I2 & $\begin{array}{ll}\hat{O} & \text { II } \\
\text { O } & \text { I2 }\end{array}$ & $22-24$ & $\begin{array}{lr}0 & \text { I7 } \\
\text { †े } & \text { I8-I9 }\end{array}$ & $34-36$ & $\begin{array}{ll}\hat{O} & 20 \\
0 & 2 \mathrm{I}\end{array}$ \\
\hline
\end{tabular}

On hatching in March and April the larvae have a carapace length of $0.9 \mathrm{~mm}$. (total length $4.2 \mathrm{~mm}$.), and by the end of June, now from 2 to 4 months old, they have metamorphosed and have a carapace length of 2.5-3 mm. Metamorphosis takes place at about $2 \cdot 2 \mathrm{~mm}$. carapace length. By the end of July they have increased their carapace length from 3 to $5 \mathrm{~mm}$., and are still juvenile, with the sexes undifferentiated. At $5 \mathrm{~mm}$. carapace length it becomes possible to distinguish the sexes by the shape of the pleopods, but the developing males at this early stage are less readily 


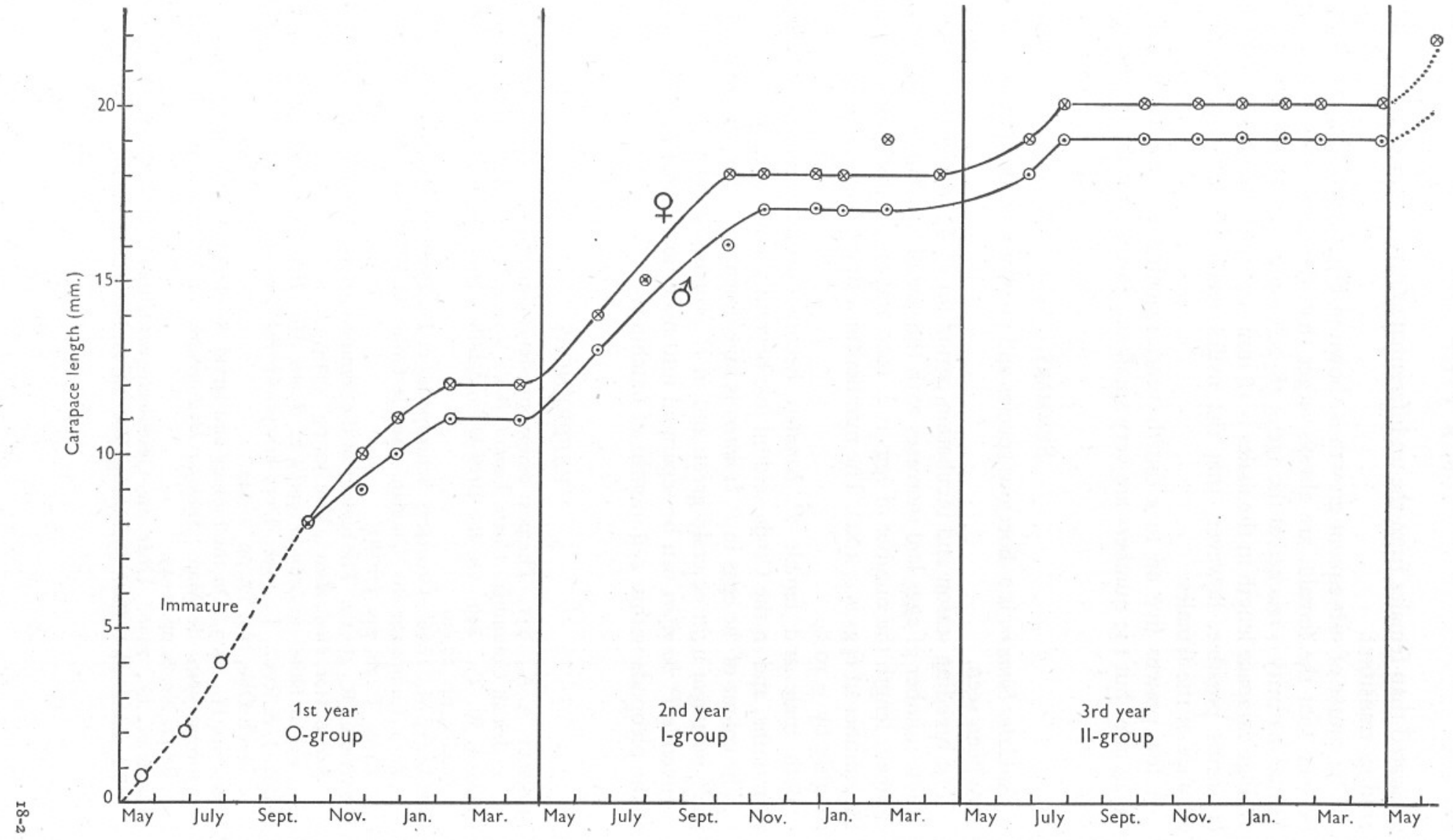

Fig. 2. Pandalus bonnieri. Modal lengths of various samples of three year-groups, forming an approximate growth curve. 
separated than females from the undifferentiated juveniles because of a more gradual transition.

The course of subsequent growth is shown in Fig. 2 and Table II. It will be seen that the females are always larger than the males of a similar age. Sexual maturity is reached at the age of $18-20$ months (i.e. October) when the average carapace length in the males is $16 \mathrm{~mm}$. and in the females $17-18 \mathrm{~mm}$. It seems possible, however, that the males reach maturity somewhat in advance of the females.

A few prawns live on to a fourth year, reaching a carapace length of 23-24 $\mathrm{mm}$. but the numbers are very small and insufficient for inclusion.

\section{SUMMARY}

Pandalus bonnieri is a dioecious species and no protandrous hermaphrodites have been seen.

The breeding season and incubation period for $P$. bonnieri are described.

The number of eggs laid increases with the size of the female. At $16 \mathrm{~mm}$. carapace length the number of eggs is $c$. 1000 and at $24 \mathrm{~mm}$. carapace length the number of eggs is $c$. 4000 . The number for a single $\mathrm{mm}$. size group varies roughly by $\pm 10 \%$.

Both male and female $P$. bonnieri become sexually mature at about I 8 months, and in the Clyde seldom live beyond 3 years of age.

The colour of the eggs in $P$. bonnieri is sage green, in $P$. borealis blue green, in $P$. montagui light emerald green and in $P$. propinquus fawn.

Juvenile $P$. bonnieri can be separated into males and females by the shape of the pleopods within 4-6 months of hatching.

\section{REFERENCES}

Berkeley, A. A., I93r. The post-embryonic development of the common pandalids of British Columbia. Contr. Canad. Biol., Vol. 4, No. 6, pp. 79-163.

Calman, W. T., I899. On the British Pandalidae. Ann. Mag. Nat. Hist., Ser. 7, Vol. 3, pp. 27-39.

CAullery, M., I896. Crustacés Schizopodes et Décapodes; Résultats Scientifiques de la Campagne du 'Caudan' dans le Golfe de Gascogne, 1895. Ann. Univ. Lyon, T. 26, pp. 377-8I.

ForsteR, G. R., I95I $a$. The biology of the common prawn, Leander serratus Pennant. fourn. Mar. Biol. Assoc., Vol. 30, pp. 333-59.

- I95I $b$. Notes on Leander squilla L. Fourn. Mar. Biol. Assoc., Vol. 30, pp. 36I-7.

HJoRT, J. \& RuUd, J., I938. Deep-sea prawn fisheries and their problems. Hvalr. Skrift. Oslo, No. I7, pp. I-I44.

Höglund, H., I943. On the biology and larval development of Leander squilla (L.) forma typica de Man. Svenska Hydrograph. Biol. Komm. Skr., N.S. (Biol.), Bd. 2, Nr. 6, pp. I-43.

JÄGERSTEN, G., I936. UUber die Geschlechtsverhältnisse und das Wachstum bei Pandalus. Ark. Zool. Stockholm, Vol. 28, A, No. 20, pp. I-26. 
KeMP, S., I9Io. The Decapod Natantia of the Coast of Ireland. Fisheries, Ireland, Sci. Invest., I908, I (1910), pp. I-I90.

Lebour, M. V., I940. The larvae of the Pandalidae. Fourn. Mar. Biol. Assoc., Vol. 24, pp. 239-52.

Marine Biological Association of the U.K., I93i. Plymouth Marine Fauna, 2nd ed.

Moore, H. B., I937. Marine Fauna of the Isle of Man. Proc. L'pool Biol. Soc., Vol. 50, pp. I-293.

Poulsen, E. M., I946. Investigations on the Danish Fishery for and the biology of the Norway Lobster and the Deep-Sea Prawn. Rept. Danish Biol. Sta., Vol. 48, pp. 25-46.

StePHENSEN, K., I939. Zoology of Iceland, Vol. 25.

Wollebaek, A., I908. Remarks on Decapod Crustaceans of the North Atlantic and the Norwegian Fjords (I and II). Bergens Mus. Aarb., Nr. 12, pp. I-77. 